\title{
Role of Mas receptor in renal blood flow response to angiotensin (1-7) in male and female rats
}

\author{
Mehdi Nematbakhsh ${ }^{1,2}$ and Tahereh Safari ${ }^{1,3}$ \\ ${ }^{1}$ Water and Electrolytes Research Center, Department of Physiology, Isfahan University of Medical Sciences, Isfahan, Iran \\ ${ }^{2}$ Isfahan ${ }^{M N}$ Institute of Basic and Applied Sciences Research, Isfahan, Iran \\ ${ }^{3}$ Department of Physiology, Zahedan University of Medical Sciences, Zahedan, Iran
}

\begin{abstract}
Epidemiologic and clinical studies have shown that progression of renal disease in male is faster than that in female. However, the exact mechanisms are not well recognized. Angiotensin (1-7) (Ang 1-7) receptor, called "Mas", is an element in the depressor arm of renin angiotensin system (RAS), and its expression is enhanced in females. We test the hypothesis that Mas receptor (MasR) blockade (A779) attenuates renal blood flow (RBF) in response to infusion of graded doses of Ang 1-7 in female rats. Male and female Wistar rats were anesthetized and catheterized. Then, the mean arterial pressure (MAP), RBF, and controlled renal perfusion pressure (RPP) responses to infusion of graded doses of Ang 1-7 (100-1000 ng/kg/min i.v) with and without A779 were measured in the animals. Basal MAP, RPP, RBF, and renal vascular resistance (RVR) were not significantly different between the two groups. After Ang 1-7 administration, RPP was controlled at a constant level. However, RBF increased in a dose-related manner in response to Ang 1-7 infusion in both male and female rats $\left(p_{\text {dose }}<0.0001\right)$, but MasR blockade significantly attenuated this response only in female $\left(p_{\text {group }}=0.04\right)$ and not male $\left(p_{\text {group }}=0.23\right)$. In addition, A779 increased the RBF response to Ang 1-7 to a greater extent. This is while the increase in male was not significant when compared with that in female ( $p_{\text {gender }}=0.08$ ). RVR response to Ang 1-7 was insignificantly attenuated by A779 in both genders. The MasR differently regulated RBF response to Ang 1-7 in the two genders, and the effect was greater in female rats. The MasR may be a target for improvement of kidney circulation in renal diseases.
\end{abstract}

Key words: Renin angiotensin system (RAS) - Mas receptor - Gender difference - Angiotensin 1-7

\section{Introduction}

Cardiovascular and kidney diseases in women have a prevalence lower than that in men (Oparil and Miller 2005), and studies have demonstrated that men are at a higher risk for development of chronic kidney diseases (Silbiger and Neugarten 1995, Neugarten 2009). The exact underlying mechanism for the difference is still not completely understood. However, it is known that renin angiotensin system (RAS) is involved (Sullivan 2008). RAS with a complex

Correspondence to: Mehdi Nematbakhsh, Water and Electrolytes Research Center, Department of Physiology, Isfahan University of Medical Sciences, Isfahan, Iran

E-mail: nematbakhsh@med.mui.ac.ir nematbakhsh@gmail.com structure plays an important role in regulation of body fluid and blood pressure.

The RAS components are sex-related, and female sex hormone; estradiol, influences the RAS activation (Fischer et al. 2002). Vasodepressor arm of RAS includes angiotensin converting enzyme type 2 (ACE 2 ), angiotensin type 2 receptor (AT2R), Mas receptor (MasR), and angiotensin (1-7) (Ang 1-7) (Dilauro and Burns 2009, Ferrario and Varagic 2010). It is known that the vasopressor effects of RAS in male (Fischer et al. 2002, McGuire et al. 2007) and vasodepressor effect in female (Sampson et al. 2008, Sullivan et al. 2010, Brown et al. 2012) have more prominent roles in the process.

Ang 1-7 is an active heptapeptide with an important role in counterbalance provided by Ang II via increasing the level of nitric oxide (NO) or prostaglandins (PGs) (Chap- 
pell et al. 1998). Therefore, Ang 1-7 has been known as a physiological antagonist for Ang II (Macova et al. 2008). ACE2 degrades Ang II to Ang 1-7 and Ang I to Ang 1-9 that may be cleaved by ACE to Ang 1-7 (Donoghue et al. 2000). The plasma level of Ang 1-7 is enhanced when ACE or Ang type 1 receptor (AT1R) are blocked; so, the effect of blockers of these agents may be mediated through Ang 1-7 (Ferrario and Chappell 2004).

By binding to MasR as a G-protein, Ang 1-7 implements its actions (Brosnihan et al. 1996, Esteban et al. 2009, Ferrario and Varagic 2010). Furthermore, the receptor has a binding affinity for AT1R and AT2R (Castro et al. 2005, Walters et al. 2005). Due to the important role of Ang 1-7 in cardiovascular and renal hemodynamics and also the growing evidence of sex differences in RAS, in this study we postulated that MasR blockade decreases renal blood flow (RBF) in response to Ang 1-7 infusion in female rats. To test this hypothesis, RBF response to infusion of graded doses of Ang 1-7 was measured in male and female rats with and without MasR antagonist (A779).

\section{Materials and Methods}

\section{Animals}

Male ( $n=11$, body weight: $201 \pm 5 \mathrm{~g})$ and female $(n=12$, body weight: $191 \pm 3 \mathrm{~g}$ ) Wistar rats were housed at the room temperature of $23-25^{\circ} \mathrm{C}$ with a 12 -h light/dark cycle and allowed to acclimatize to the conditions for one week. The rats were fed with rat chow and water ad libitum. The experiments were in advance approved by the Isfahan University of Medical Sciences Ethics Committee.

\section{Surgical procedure}

The rats were anaesthetized with thiobutabarbital (Inactin, 150 mg/kg; Sigma Chemical Company, St. Louis, MO, USA) and the trachea was cannulated. Catheters were implanted into the jugular vein, and carotid and femoral arteries. To keep the animal adequately hydrated, during the surgery $2 \%$ bovine serum albumin at the rate of $2 \mathrm{ml} / 100 \mathrm{~g} / \mathrm{h}$ was infused via the jugular vein. The pressure of femoral artery was considered as the renal perfusion pressure (RPP). To control RPP at the basal level during infusion of Ang 1-7, an adjustable clamp was placed around the aorta above the level of the renal arteries. The arterial catheters were connected to pressure transducers and a bridge amplifier (Scientific Concepts, Vic., Melbourne, Australia) and mean arterial pressure (MAP) and RPP were measured from the carotid and femoral arteries, respectively. The left kidney was very carefully exposed and placed in a cup secured to the operating table. A transit-time ultrasonic flow probe (Type 2SB;
Transonic Systems, Ithaca, NY, USA) was placed around the renal artery to facilitate the RBF measurement. The transittime ultrasonic flow probe was interfaced with a compatible flowmeter (T108; Transonic Systems). MAP, RPP, and RBF were continuously measured throughout the experiment and the data were captured as 2-second averages via a data acquisition system. Renal vascular resistance (RVR) was calculated as RPP/RBF ratio.

At the completion of the surgery, a 30-60 min period was allowed for equilibration before beginning the experimental manipulations. At this stage, animals with abnormal variation in MAP or RPP or any other abnormalities were omitted from the study.

\section{Experimental design}

MAP, RPP, and RBF were continuously measured in all animals during the equilibration phase. Then, MasR antagonist; A779, (male; $n=6$, female; $n=6$ ) or vehicle (male; $n=5$, female; $n=6$ ) were administrated through the vein catheter. A779 (Bachem Bioscience Inc., King of Prussia, PA, USA) dissolved in $0.9 \% \mathrm{w} / \mathrm{v}$ saline and administered as bolus doses of $50 \mu \mathrm{g} / \mathrm{kg}$ followed by continuous infusions at $50 \mu \mathrm{g} / \mathrm{kg} / \mathrm{h}$. A779 is a selective MasR antagonist and demonstrates negligible affinity for AT1R and AT2R (Santoset al. 1994, Santos 2003, Bosnyak et al. 2011). Twenty min after the infusion was initiated; MAP, RPP, and RBF were determined over a 10 -min period. The data collected at this stage was considered as the baseline data prior to Ang 1-7 administration.

Using a microsyringe pump (New Era Pump System Inc. Farmingdale, NY, USA), intravenous infusion of Ang 1-7 (Sigma Chemical Company, St. Louis, MO, USA) at graded doses $(100,300$, and $1000 \mathrm{ng} / \mathrm{kg} / \mathrm{min})$ was performed 30 min after initiation of the antagonist infusion. Each dose was administered until the MAP response reached equilibrium (approx. $15 \mathrm{~min}$ ). Throughout the experiment, RPP was maintained at pre-Ang 1-7 infusion levels via manipulation of the aortic clamp. MAP, RPP, and RBF responses were determined over the final $5 \mathrm{~min}$ of each infusion. At the end of the experiment, the rats were humanely killed via anesthetic overdose, and their left kidneys were removed and weighted immediately.

\section{Statistical analysis}

Data are expressed as mean \pm SEM and analyzed using the SPSS software, version 16. The A779- and vehicletreated animals were compared with regard to the basal data (before Ang 1-7) using the unpaired Student's $t$ - test. The responses to Ang 1-7 are reported as percentage (\%) of change from the baseline values, and compared via repeated measures ANOVA for the different groups 
of factors (vehicle, A779) and doses (100, 300, $1000 \mathrm{ng} /$ $\mathrm{kg} / \mathrm{min}$ Ang 1-7) and their interaction. Similar analysis was applied for percentage of change in $\mathrm{RBF}$ response to Ang 1-7 for the different groups of factors (male, female) and doses of Ang 1-7 and their interaction. $p<0.05$ was considered statistically significant.

\section{Results}

\section{Baseline measurements}

Left kidney weights were used in our study weighing 0.82 $\pm 0.02 \mathrm{~g}$ (male) and $0.77 \pm 0.02 \mathrm{~g}$ (female), which were significantly different $(p<0.001)$. However, no significant difference was detected in kidney/100 g b.w. ratio between the sexes (male: $0.410 \pm 0.015$ and female: $0.406 \pm 0.012$ $\mathrm{g} / 100 \mathrm{~g}$ b.w.). The data obtained from "before Ang 1-7" stages as the basal values indicated that there were no significant differences between the groups in MAP, RPP, RVR, or RBF values corrected for kidney weight (Fig. 1).

\section{Responses to Ang 1-7 infusion}

Ang 1-7 infusion significantly increased percentage of change of MAP in male $\left(p_{\text {dose }}<0.0001\right)$, but this was not the case in female (Fig. 2). However, in both sexes, percentage of change of MAP was not significantly different between A779- and vehicle-treated animals (both sexes, $p>0.05)$. As mentioned before, RPP was maintained at the basal value by adjustable clamp placed around the aorta above the level of the renal arteries. Therefore, percentage of change in RPP was almost constant during Ang 1-7 infusion with no significant difference between A779- and vehicle-treated animals in both sexes (Fig. 2). In both sexes, Ang 1-7 infusion increased percentage of change of RBF in a dose-related manner (both sexes, $p_{\text {dose }}<0.0001$ ) with a greater response in male. However, significant difference between A779- and vehicle-treated animals was observed only in female rats $\left(p_{\text {group }}=0.04\right)$; indicating that A779 significantly attenuates RBF response to Ang 1-7 in female but not in male. Ang 1-7 infusion decreased percentage of change of RVR in a dose-related manner (both sexes, $p_{\text {dose }}<$
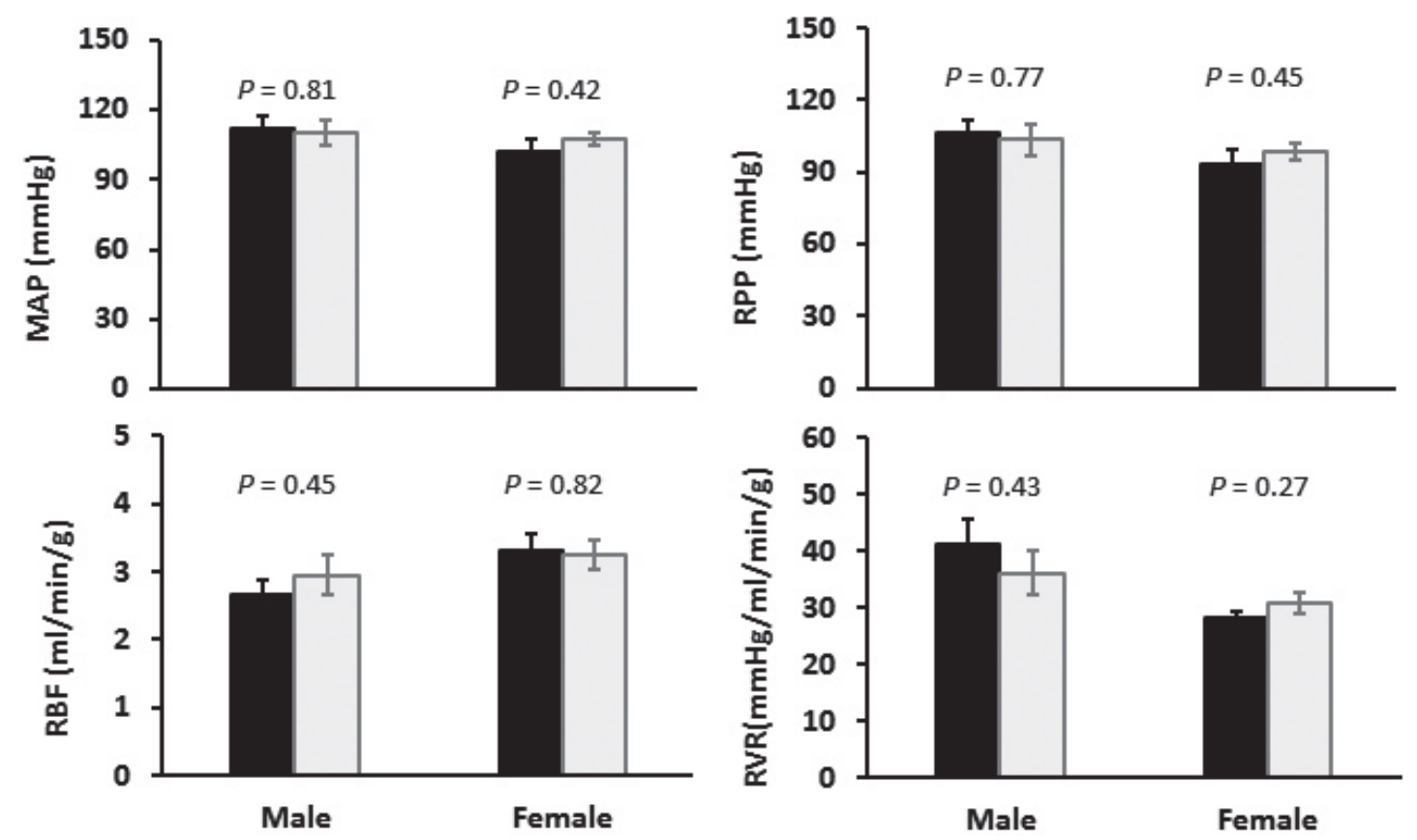

Figure 1. Hemodynamic variables before Ang 1-7 infusion as basal data. Data are presented as mean \pm SEM. The $p$ values were derived from Student t-test. MAP, mean arterial pressure; RPP, renal perfusion pressure; RVR, renal vascular resistance; RBF, renal blood flow per gram kidney weight. 

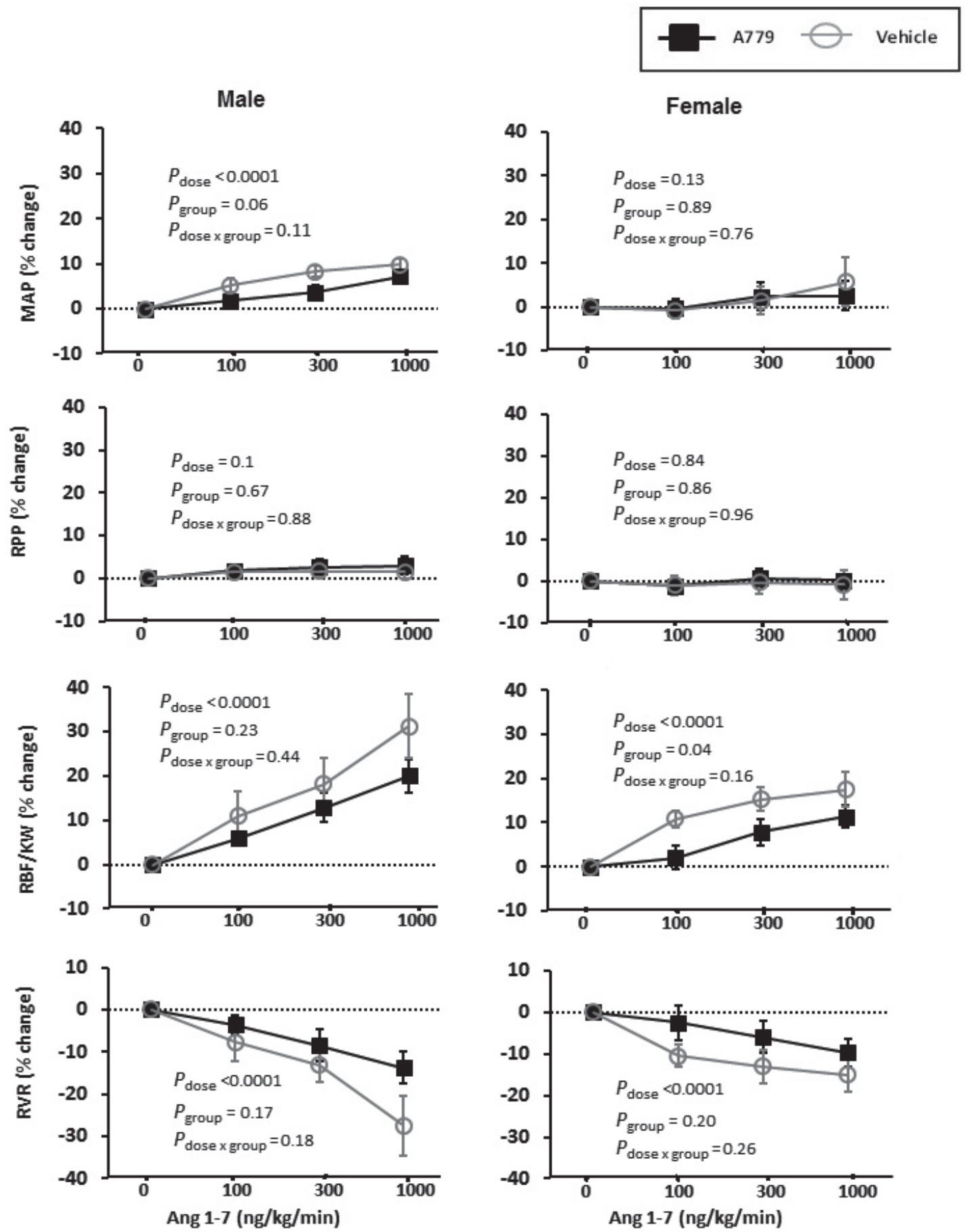

Figure 2. Effects of vehicle and A779 on responses to Ang 1-7 infusion. Data are shown as mean \pm SEM of percentage of changes from the baseline in mean arterial pressure (MAP), renal perfusion pressure (RPP), renal blood flow (RBF), and renal vascular resistance (RVR). The $p$ values were derived from two-way ANOVA for repeated measures with factor groups, Ang 1-7 dose, and their interaction.

0.0001). However, there was no statistically significant difference in percentage of change of RVR between the groups in both sexes (Fig. 2). Percentage of change in RBF response to Ang 1-7 was also compared between male and female rats. The analyses indicated that A779 increased RBF response to Ang 1-7 to a greater extent but insignificantly in male compared with that in female ( $\left.p_{\text {gender }}=0.08\right)$. However, when MasR was not blocked (vehicle-treated), 

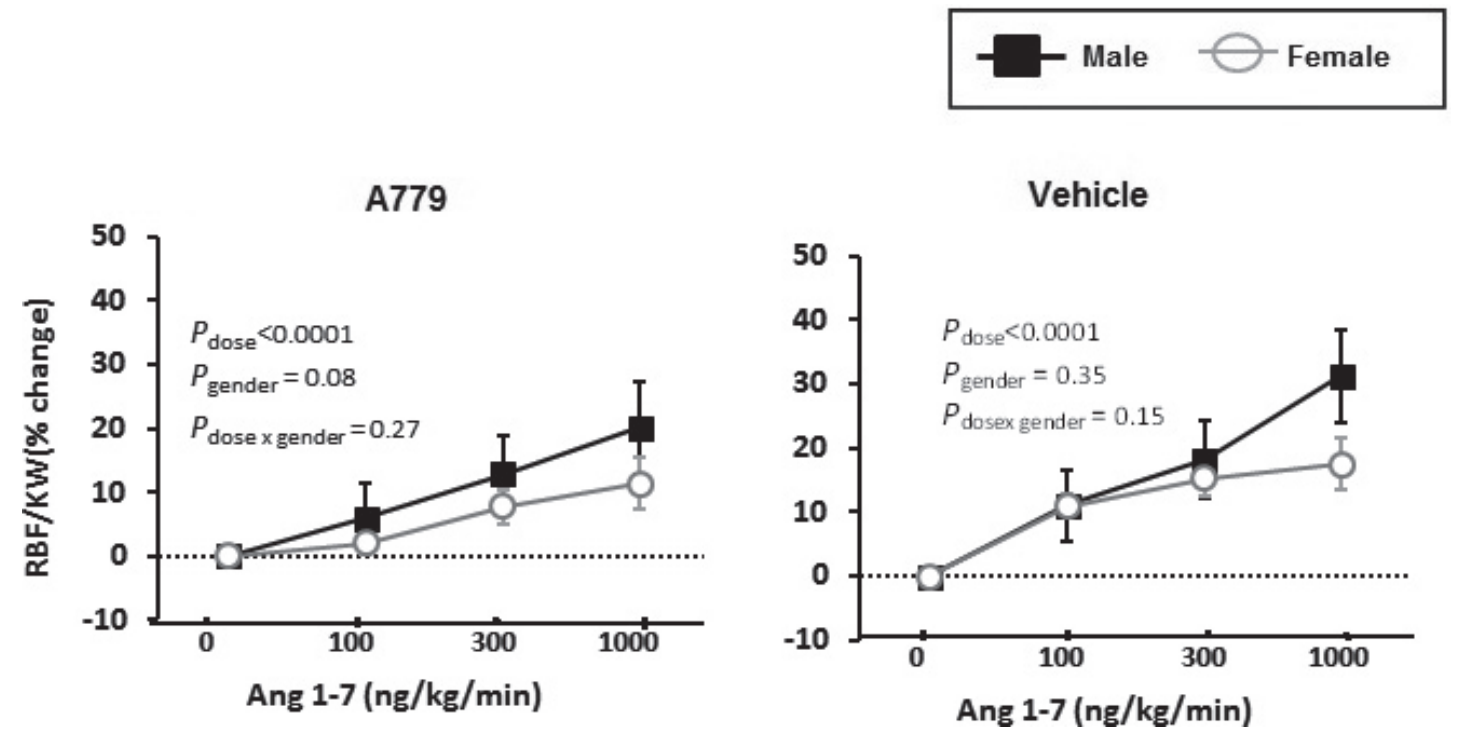

Figure 3. Responses to Ang 1-7 infusion between male and female animals treated with A779 or vehicle. Data are shown as mean \pm SEM of percentage of changes from the baseline in renal blood flow (RBF). The $p$ values were derived from two-way ANOVA for repeated measures with factor genders, Ang 1-7 dose, and their interaction.

RBF response to Ang 1-7 was not different between genders $\left(p_{\text {gender }}=0.35\right)($ Fig. 3)

\section{Discussion}

In the present study, we found that MasR blockade increased $\mathrm{RBF}$ response to Ang 1-7 to a greater extent in male compared with that in female. A779 also decreased RBF response to Ang 1-7 in both sexes when compared with the control (vehicle) group. However, the decrease was significant in female.

In several studies, the vasodilatory effect of Ang 1-7 in blood circulation has been confirmed on coronary artery ring of dogs and pigs (Brosnihan et al. 1996, Porsti et al. 1996), the mesenteric circulation (Osei et al. 1993), and also on systemic normotensive (Benter et al. 1993) and hypertensive (Nakamoto et al. 1995) animals. Sampaio et al. reported that in male Wistar rats, RBF decreases by administration of MasR antagonist (A779) due to increase in vascular resistance, and co-administration of Ang 1-7 (110 femtomol/min/10 min) did not significantly alter the RBF (Sampaio et al. 2003). Ang 1-7 can be locally formed in kidney (Hilchey and Bell-Quilley 1995, Simoes-e-Silva et al. 1997, Santos et al. 2000, Souza Dos Santos et al. 2001), and MasR is expressed in renal proximal tubular cells (Moon 2011). So, it is expected that the kidney vascular bed is a sensitive site for Ang 1-7 response. Many studies suggested that the effect of Ang 1-7 is inhibited by A779 administration, and this vasodilatory effect may be related to NO production (Brosnihan et al. 1996, Porsti et al. 1996, Li et al. 1997; Heitsch et al. 2001; Ren et al. 2002). In addition, Ang 1-7 promotes the vasodilatory effect of bradykinin (Brosnihan et al. 1996; Oliveira et al. 1999; Almeida et al. 2000; Fernandes et al. 2001), and its vasodilatory effect in the kidney was also demonstrated by an increase in the glomerular filtration rate (Hilchey and Bell-Quilley 1995; Kucharewicz et al. 2002). In fact, Ang 1-7 is a counter-regulator of Ang II (Brosnihan et al. 1996), and it has low binding affinity to AT1R (Moon 2011). On the contrary, under physiologic circumstances, Ang 1-7 may has no effect on kidney hemodynamics (Van der Wouden et al. 2006).

Another point is related to AT1R that can be antagonized by MasR (Moon 2011) possibly due to hetero-oligomerization resulted from interaction between MasR and AT1R, which inhibits AT1R (Mercure et al. 2008). Therefore, our findings support the vasodilatory effect of Ang 1-7 on renal vascular bed; possibly due to increased production of NO, or potentiation of vasodilatory effect of bradykinin, or counterregulation of Ang II.

In the current study, female rats provided a lower response to Ang 1-7 compared to male rats. The difference in the response was statistically significant $(p=0.08)$ when MasR was blocked. Also in female rats, A779 compared to vehicle significantly attenuated the RBF response to Ang 1-7, while this finding was insignificant in male rats. Previous reports indicated that infusion of $\mathrm{A} 779$ reduces RBF in male rats (Sampaio et al. 2003), and increases urine volume in female rats (Joyner et al. 2008). The difference in RBF 
response to Ang 1-7 between male and female rats seems to be related to RAS receptors. The number of AT1R in male rats is higher than that in female rats, which is mediated by the effect of sex hormones; especially estrogen (Armando et al. 2002), and the Ang II-induced vasoconstriction could be inhibited by Ang 1-7 (Mahon et al. 1994). So, it seems that the effect of MasR to antagonize AT1R is more prominent in male than female. Sex hormone of estrogen is another factor. Estrogen via releasing NO increases blood flow (Fogelberg et al. 1990), and NO play an important role in vasodilatory effect of Ang 1-7 (Osei et al. 1993, Brosnihan et al. 1996, Porsti et al. 1996). Female sex hormone also upregulates AT2R (Armando et al. 2002). However, the role of estrogen on MasR expression in female is not clear. In this regard, previous studies have shown that expression of MasR in female rats is more than that in male rats (Sampson et al. 2012), and AT2R/AT1R ratio in female is higher than that in male (Silva-Antonialli et al. 2004). Consequently, the possibility of interaction between MasR and AT2R in female is higher (Safari et al. 2012). Therefore, when MasR is blocked, the gender difference in RBF response to Ang 1-7 may be related to Ang II receptors, which attenuate RBF response to Ang 1-7 in female. Also, in general, considering the higher expression of MasR and the release of NO by estrogen in female, lower response to Ang 1-7 in female is more expected than in male.

\section{Conclusion}

The MasR and Ang 1-7 infusion differentially regulated renal hemodynamics in two sexes. The MasR may be considered as a therapeutic target for treatment of kidney diseases.

Acknowledgements. This research was supported by Isfahan University of Medical Sciences (Grant \# 189021).

Conflict of interests. The authors declare no conflict of interests.

\section{References}

Almeida A. P., Frábregas B. C., Madureira M. M., Santos R. J., Campagnole-Santos M. J., Santos R. A. (2000): Angiotensin(1-7) potentiates the coronary vasodilatatory effect of bradykinin in the isolated rat heart. Braz. J. Med. Biol. Res. 33, 709-713

http://dx.doi.org/10.1590/S0100-879X2000000600012

Armando I., Jezova M., Juorio A. V., Terron J. A., Falco-Neri A., Semino-Mora C., Imboden H., Saavedra J. M. (2002): Estrogen upregulates renal angiotensin II AT2receptors. Am. J. Physiol. Renal. Physiol. 283, F934 http://dx.doi.org/10.1152/ajprenal.00145.2002

Benter I. F., Diz D. I., Ferrario C. M. (1993): Cardiovascular actions of angiotensin (1-7). Peptides 14, 679-684
http://dx.doi.org/10.1016/0196-9781(93)90097-Z

Bosnyak S., Jones E. S., Christopoulos A., Aguilar M. I., Thomas W. G., Widdop R. E. (2011): Relative affinity of angiotensin peptides and novel ligands at AT1 and AT2 receptors. Clin. Sci. (Lond) 121, 297-303

Brosnihan K. B., Li K., Ferrario C. M. (1996): Angiotensin-(1-7) dilates canine coronary arteries through kinins and nitric oxide. Hypertension 27, 523-528 http://dx.doi.org/10.1161/01.HYP.27.3.523

Brown R. D., Hilliard L. M., Head G. A., Jones E. S., Widdop R. E., Denton K. M. (2012): Sex differences in the pressor and tubuloglomerular feedback response to angiotensin II. Hypertension 59, 129-135 http://dx.doi.org/10.1161/HYPERTENSIONAHA.111.178715

Castro C. H., Santos R. A., Ferreira A. J., Bader M., Alenina N., Almeida A. P. (2005): Evidence for a functional interaction of the angiotensin-(1-7) receptor Mas with AT1 and AT2 receptors in the mouse heart. Hypertension 46, 937-942 http://dx.doi.org/10.1161/01.HYP.0000175813.04375.8a

Chappell M. C., Diz D. I., Yunis C., Ferrario C. M. (1998): Differential actions of angiotensin-(1-7) in the kidney. Kidney Int. 54, S3-6 http://dx.doi.org/10.1038/sj.ki.4490555

Dilauro M., Burns K. D. (2009): Angiotensin-(1-7) and its effects in the kidney. ScientificWorld Journal 9, 522-535 http://dx.doi.org/10.1100/tsw.2009.70

Donoghue M., Hsieh F., Baronas E., Godbout K., Gosselin M., Stagliano N., Donovan M., Woolf B., Robison K., Jeyaseelan R. (2000): A novel angiotensin-converting enzyme 2 related carboxypeptidase (ACE2) converts angiotensin I to angiotensin 1-9. Circ. Res. 87, e1-e9 http://dx.doi.org/10.1161/01.RES.87.5.e1

Esteban V., Heringer-Walther S., Sterner-Kock A., De Bruin R., Van Den Engel S., Wang Y., Mezzano S., Egido J., Schultheiss H. P., Ruiz-Ortega M. (2009): Angiotensin-(1-7) and the G proteincoupled receptor Mas are key players in renal inflammation. PLoS One 4, e5406

http://dx.doi.org/10.1371/journal.pone.0005406

Fernandes L., Fortes Z. B., Nigro D., Tostes R. C. A., Santos R. A. S., de Carvalho M. H. C. (2001): Potentiation of bradykinin by angiotensin-(1-7) on arterioles of spontaneously hypertensive rats studied in vivo. Hypertension 37, 703-709 http://dx.doi.org/10.1161/01.HYP.37.2.703

Ferrario C., Chappell M. (2004): Novel angiotensin peptide. Cell. Mol. Life Sci. 61, 2720-2727 http://dx.doi.org/10.1007/s00018-004-4243-4

Ferrario C. M., Varagic J. (2010): The ANG-(1-7)/ACE2/mas axis in the regulation of nephron function. Am. J. Physiol. Renal Physiol. 298, F1297-1305 http://dx.doi.org/10.1152/ajprenal.00110.2010

Fischer M., Baessler A., Schunkert H. (2002): Renin angiotensin system and gender differences in the cardiovascular system. Cardiovasc. Res. 53, 672 http://dx.doi.org/10.1016/S0008-6363(01)00479-5

Fogelberg M., Vesterqvist O., Diczfalusy U., Henriksson P. (1990): Experimental atherosclerosis: effects of oestrogen and atherosclerosis on thromboxane and prostacyclin formation. Eur. J. Clin. Invest. 20, 105-110 
http://dx.doi.org/10.1111/j.1365-2362.1990.tb01799.x

Heitsch H., Brovkovych S., Malinski T., Wiemer G. (2001): Angiotensin-(1-7)-stimulated nitric oxide and superoxide release from endothelial cells. Hypertension 37, 72-76 http://dx.doi.org/10.1161/01.HYP.37.1.72

Hilchey S. D., Bell-Quilley C. P. (1995): Association between the natriuretic action of angiotensin-(1-7) and selective stimulation of renal prostaglandin I2 release. Hypertension 25, 1238-1244 http://dx.doi.org/10.1161/01.HYP.25.6.1238

Joyner J., Neves L. A., Stovall K., Ferrario C. M., Brosnihan K. B. (2008): Angiotensin-(1-7) serves as an aquaretic by increasing water intake and diuresis in association with downregulation of aquaporin-1 during pregnancy in rats. Am. J. Physiol. Regul. Integr. Comp. Physiol. 294, R1073-1080 http://dx.doi.org/10.1152/ajpregu.00572.2007

Kucharewicz I., Pawlak R., Matys T., Pawlak D., Buczko W. (2002): Antithrombotic effect of captopril and losartan is mediated by angiotensin-(1-7). Hypertension 40, 774-779 http://dx.doi.org/10.1161/01.HYP.0000035396.27909.40

Li P., Chappell M. C., Ferrario C. M., Brosnihan K. B. (1997): Angiotensin-(1-7) augments bradykinin-induced vasodilation by competing with ACE and releasing nitric oxide. Hypertension 29, 394-398 http://dx.doi.org/10.1161/01.HYP.29.1.394

Macova M., Armando I., Zhou J., Baiardi G., Tyurmin D., Larrayoz-Roldan I., Saavedra J. M. (2008): Estrogen reduces aldosterone, upregulates adrenal angiotensin II AT 2 receptors and normalizes adrenomedullary Fra- 2 in ovariectomized rats. Neuroendocrinology 88, 276-286 http://dx.doi.org/10.1159/000150977

Mahon J. M., Carr R. D., Nicol A. K., Henderson I. W. (1994): Angiotensin(1-7) is an antagonist at the type 1 angiotensin II receptor. J. Hypertens. 12, 1377-1381 http://dx.doi.org/10.1097/00004872-199412000-00010

McGuire B. B., Watson R. W., Perez-Barriocanal F., Fitzpatrick J. M., Docherty N. G. (2007): Gender differences in the reninangiotensin and nitric oxide systems: relevance in the normal and diseased kidney. Kidney Blood Press. Res. 30, 67-80 http://dx.doi.org/10.1159/000099150

Mercure C., Yogi A., Callera G. E., Aranha A. B., Bader M., Ferreira A. J., Santos R. A. S., Walther T., Touyz R. M., Reudelhuber T. L. (2008): Angiotensin (1-7) blunts hypertensive cardiac remodeling by a direct effect on the heart. Circ. Res. 103, 1319-1326 http://dx.doi.org/10.1161/CIRCRESAHA.108.184911

Moon J. Y. (2011): ACE2 and Angiotensin-(1-7) in hypertensive renal disease. Electrolyte Blood Press. 9, 41-44 http://dx.doi.org/10.5049/EBP.2011.9.2.41

Nakamoto H., Ferrario C. M., Fuller S. B., Robaczewski D. L., Winicov E., Dean R. H. (1995): Angiotensin-(1-7) and nitric oxide interaction in renovascular hypertension. Hypertension 25, 796-802 http://dx.doi.org/10.1161/01.HYP.25.4.796

Neugarten J. (2009): Gender and the progression of renal disease. J. Am. Soc. Nephrol. 13, 2807-2809 http://dx.doi.org/10.1097/01.ASN.0000035846.89753.D4

Oliveira M., Fortes Z., Santos R., Kosla M. C., De Carvalho M. (1999): Synergistic effect of angiotensin-(1-7) on bradykinin arteriolar dilation in vivo. Peptides 20, 1195
http://dx.doi.org/10.1016/S0196-9781(99)00123-0

Oparil S., Miller A. P. (2005): Gender and blood pressure. J. Clin. Hypertens. 7, 300-309

http://dx.doi.org/10.1111/j.1524-6175.2005.04087.x

Osei S. Y., Ahima R. S., Minkes R. K., Weaver J. P., Khosla M. C., Kadowitz P. J. (1993): Differential responses to angiotensin-(17) in the feline mesenteric and hindquarters vascular beds. Eur. J. Pharmacol. 234, 35-42 http://dx.doi.org/10.1016/0014-2999(93)90703-K

Porsti I., Bara A. T., Busse R., Hecker M. (1996): Release of nitric oxide by angiotensin-(1-7) from porcine coronary endothelium: implications for a novel angiotensin receptor. Br. J. Pharmacol. 111, 652-654 http://dx.doi.org/10.1111/j.1476-5381.1994.tb14787.x

Ren Y. L., Garvin J. L., Carretero O. A. (2002): Vasodilator action of angiotensin-(1-7) on isolated rabbit afferent arterioles. Hypertension 39, 799-802 http://dx.doi.org/10.1161/hy0302.104673

Safari T., Nematbakhsh M., Hilliard L. M., Evans R. G., Denton K. M. (2012): Sex differences in the renal vascular response to angiotensin II involves the Mas receptor. Acta Physiol. 206, 150-156 http://dx.doi.org/10.1111/j.1748-1716.2012.02468.x

Sampaio W. O., Nascimento A. A. S., Santos R. A. S. (2003): Systemic and regional hemodynamic effects of angiotensin-(1-7) in rats. Am. J. Physiol. Heart Circ. Physiol. 284, H1985

Sampson A. K., Moritz K. M., Jones E. S., Flower R. L., Widdop R. E., Denton K. M. (2008): Enhanced angiotensin II type 2 receptor mechanisms mediate decreases in arterial pressure attributable to chronic low-dose angiotensin II in female rats. Hypertension 52, 666-671

http://dx.doi.org/10.1161/HYPERTENSIONAHA.108.114058

Sampson A. K., Moritz K. M., Denton K. M. (2012): Postnatal ontogeny of angiotensin receptors and ACE2 in male and female rats. Gender medicine 9, 21-32 http://dx.doi.org/10.1016/j.genm.2011.12.003

Santos R. A. S., Campagnole-Santos M. J., Baracho N. C. V., Fontes M. A. P., Silva L., Neves L. A. A., Oliveira D. R., Caligiorne S. M., Rodrigues A. R. V., Gropen C. (1994): Characterization of a new angiotensin antagonist selective for angiotensin-(1-7): evidence that the actions of angiotensin-(1-7) are mediated by specific angiotensin receptors. Brain Res. Bull. 35, 293-298 http://dx.doi.org/10.1016/0361-9230(94)90104-X

Santos R. A. S., Campagnole-Santos M. J., Andrade S. P. (2000): Angiotensin-(1-7): an update. Regul. Pept. 91, 45-62 http://dx.doi.org/10.1016/S0167-0115(00)00138-5

Santos R. A. S. (2003): Angiotensin-(1-7) is an endogenous ligand for the $G$ protein-coupled receptor Mas. Proc. Natl. Acad. Sci. 100, 8258 http://dx.doi.org/10.1073/pnas.1432869100

Silbiger S. R., Neugarten J. (1995): The impact of gender on the progression of chronic renal disease. Am. J. Kidney Dis. 25, 515-533 http://dx.doi.org/10.1016/0272-6386(95)90119-1

Silva-Antonialli M. M., Tostes R. C. A., Fernandes L., Fior-Chadi D. R., Akamine E. H., Carvalho M. H. C., Fortes Z. B., Nigro D. (2004): A lower ratio of AT1/AT2 receptors of angiotensin 
II is found in female than in male spontaneously hypertensive rats. Cardiovasc. Res. 62, 587-593

http://dx.doi.org/10.1016/j.cardiores.2004.01.020

Simoes-e-Silva A., Baracho N., Passaglio K., Santos R. (1997): Renal actions of angiotensin-(1-7). Braz. J. Med. Biol. Res. 30, 503-513 http://dx.doi.org/10.1590/S0100-879X1997000400012

Souza Dos Santos R. A., Passaglio K. T., Pesquero J. B., Bader M., Simoes E. S. A. C. (2001): Interactions between angiotensin(1-7), kinins, and angiotensin II in kidney and blood vessels. Hypertension 38, 660-664 http://dx.doi.org/10.1161/01.HYP.38.3.660

Sullivan J. C. (2008). Sex and the renin-angiotensin system: inequality between the sexes in response to RAS stimulation and inhibition. Am. J. Physiol. Regul. Integr. Comp. Physiol. 294, R1220-1226

http://dx.doi.org/10.1152/ajpregu.00864.2007
Sullivan J. C., Bhatia K., Yamamoto T., Elmarakby A. A. (2010): Angiotensin (1-7) receptor antagonism equalizes angiotensin II-induced hypertension in male and female spontaneously hypertensive rats. Hypertension 56, 658 http://dx.doi.org/10.1161/HYPERTENSIONAHA.110.153668 Van der Wouden E. A., Ochodnicky P., van Dokkum R. P., Roks A. J., Deelman R. E., de Zeeuw D., Henning R. H. (2006): The role of angiotensin(1-7) in renal vasculature of the rat. J. Hypertens. 24, 1971-1978 http://dx.doi.org/10.1097/01.hjh.0000244945.42169.c0

Walters P. E., Gaspari T. A., Widdop R. E. (2005): Angiotensin-(1-7) acts as a vasodepressor agent via angiotensin II type 2 receptors in conscious rats. Hypertension 45, 960-966 http://dx.doi.org/10.1161/01.HYP.0000160325.59323.b8

Received: August 5, 2013

Final version accepted: February 12, 2014 